\title{
14th International Chromosome Conference
}

\author{
September 4-8, 2001, Würzburg, Germany
}

The present special issue of Cytogenetics and Cell Genetics is published on the occasion of the 14th International Chromosome Conference (14th ICC) to be held from September 4 to 8, 2001 in Würzburg, Germany. Most articles published in this volume have been contributed by active participants of the meeting. I am very thankful to the authors for having provided their articles within a very short period of time, as well as to all expert reviewers for their excellent assistance.

The International Chromosome Conferences have evolved from the Oxford Chromosome Conferences, inaugurated by the late C.D. Darlington and K.R. Lewis in 1964, 1967 and 1970. The previous International Chromosomes Conferences were held at Jerusalem, Israel (1972), at Leiden, The Netherlands (1974), Helsinki, Finland (1977), Oxford, England (1980), Lübeck, Germany (1983), Marseille, France (1986), Uppsala, Sweden (1989), Edinburgh, Great Britain (1992), El Escorial, Madrid, Spain (1995), and Ancona, Italy (1998).

Since the early days of these conferences, they have brought together scientists from various fields of research whose common interest is the study of chromosome structure, function and evolution. The basic concept of these conferences has always been personal exchange of scientific results and ideas across various disciplines. They thus are truly interdisciplinary, and attract a wide range of scientists, from cytogeneticists to molecular geneticists, from evolutionary biologists to human geneticists and cancer specialists.

Historically, the University of Würzburg has a long-standing tradition of chromosome studies. One of the outstanding early scientists who did research on chromosomes was Theodor Boveri, who worked at the University of Würzburg. Boveri is one of the founders of the chromosome theory of heredity, and as early as 1914 he predicted the importance of chromosome abnormalities in cancer. I am very pleased that the 14th $I C C$, as the first of these conferences in the new millennium, is taking place in Würzburg.

Although a city of only 130,000 inhabitants, Würzburg is the administrative capital of the Lower Franconian Region and rich in museums, historical buildings and wine-lovers. Every visitor to Würzburg climbs up to the monumental Fortress that overlooks the river Main, and pays a visit to the baroque Residence with its famous Tiepolo paintings.

The 14th ICC is organized on behalf of the Standing Committee of the International Chromosome Conferences by the Department of Human Genetics of the University of Würzburg. Many colleagues of the Biocenter of the University of Würzburg (Departments of Cell and Developmental Biology, Genetics, Physiological Chemistry I) have provided essential help during the organization of the 14th ICC. My special thanks go to Martina Guttenbach, Ricardo Benavente, Indrajit Nanda, Claus Steinlein and Holger Hoehn for their enduring and patient efforts.

The 14th ICC takes place at the Philosophy Center of the Würzburg University. More than 400 delegates from 36 nations have registered for the conference. Nearly 200 posters are on permanent display during the five days of the conference. 53 invited speakers in the Main Sessions and 65 speakers in the Concurrent Symposia are presenting lectures on Human Cytogenetics, Animal Cytogenetics, Plant Cytogenetics, Sex Chromosomes, Chromosome and Genome Structure, Chromosome Evolution, Epigenetics and Methylation, Tumor Cytogenetics, Interphase Cytogenetics, Meiosis, Centromeres and Telomeres, and New Meth- 
odologies. The conference will conclude with a special Main Session dedicated to the manifold scientific contributions and hypotheses of Theodor Boveri that have influenced Genetics, Cell Biology and Developmental Biology, including some important biographical notes on this far-sighted pioneer of modern day chromosome research. The proceedings of this 14 th ICC will appear under the title Chromosomes Today, Volume 14.

I am grateful to the German Society of Human Genetics and the 'Graduiertenkolleg 639 (Tumorinstabilität)' of the University of Würzburg for the generous financial support of the 14th ICC. I should like to thank all those who made the 14th ICC possible: the members of the various committees and commissions, the invited speakers and delegates, the publishers, the commercial exhibitors, and many volunteer helpers.

Finally, I thank Judith Hartz (New York; Managing Editor of Cytogenetics and Cell Genetics) and Rolf Steinebrunner (Basel; Product Manager of S. KARGER AG) in assisting with many tasks associated with the preparation of this special issue.

Together with my colleagues I look forward to the events of the 14 th ICC, and very much hope that your stay will be most successful and enjoyable. Thank you for coming to Würzburg and sharing your insights with colleagues from all over the world.

Michael Schmid

Würzburg, September 2001 